\title{
High temperature induced "glaze" layer formed in HVOF-sprayed NiCrWMoCuCBFe coating and its wear reduction mechanism
}

\author{
Yijing WANG ${ }^{1,2}$, Xiaoqin ZHAO ${ }^{1, *}$, Enkang HAO ${ }^{1,2}$, Zhenyu BU ${ }^{1,2}$, Yulong AN ${ }^{1,2, *}$, Huidi ZHOU ${ }^{1,2}$, Jianmin CHEN ${ }^{1,2}$ \\ ${ }^{1}$ State Key Laboratory of Solid Lubrication, Lanzhou Institute of Chemical Physics, Chinese Academy of Sciences, Lanzhou 730000, China \\ ${ }^{2}$ Center of Materials Science and Optoelectronics Engineering, University of Chinese Academy of Sciences, Beijing 100049, China \\ Received: 14 May 2021 / Revised: 29 June 2021 / Accepted: 20 September 2021
}

(C) The author(s) 2021 .

\begin{abstract}
The in-situ formation of oxides on alloy surface induced by high temperature can effectively reduce wear and resist oxidation. In consideration of the solid solution strengthening effect and great oxidation resistance of additional elements at elevated temperature, the NiCrWMoCuCBFe coating was prepared by high velocity oxygen flame (HVOF) spraying technology, and its tribological behavior was scrutinized from 25 to $800{ }^{\circ} \mathrm{C}$. By means of high temperature Vickers hardness tester and high temperature X-ray diffractometer, the mechanical properties and microstructures of $\mathrm{NiCrWMoCuCBFe}$ coating were measured. And the effect of the mechanical properties and microstructures of the coating on tribological performance was discussed in detail. The results showed both its friction coefficient $(0.37)$ and wear rate $\left(5.067 \times 10^{-6} \mathrm{~mm}^{3} \cdot \mathrm{N}^{-1} \cdot \mathrm{m}^{-1}\right)$ at $800{ }^{\circ} \mathrm{C}$ were the lowest, which was mainly related to the formation of "glaze" layer on the coating surface at high temperature. The glaze layer consisted of two parts, which were $\mathrm{NiCr}_{2} \mathrm{O}_{4}$ oxide film with the ability of interlaminar slip formed in the outer layer and nano-grains existed in the inner layer. Worth mentioning, these nano-grains provided bearing capability while the oxide film was vital to reduce wear rate and friction coefficient. As the ambient temperature increased, many hard oxides were produced on the wear scars, including $\mathrm{NiO}, \mathrm{Cr}_{2} \mathrm{O}_{3}$, $\mathrm{MoO}_{3}$, and $\mathrm{Mo}_{2} \mathrm{C}$. They can improve tribological and mechanical properties of $\mathrm{NiCrWMoCuCBFe}$ coating at a wide temperature range.
\end{abstract}

Keywords: high temperature; wear and friction; NiCrWMoCuCBFe coating; in-situ oxidation; glaze layer; mechanical properties

\section{Introduction}

There are numerous mechanical components serving at high temperature applications (energy exploration, mechanical metallurgy, aerospace, and many other fields), such as high-temperature bearings, valves, and hot end parts of gas turbines. They not only need to withstand the severe oxidation and degraded mechanical properties caused by high temperature, but also should have excellent resistance to deal with tribological issues during service. The synergistic effect of high temperature and wear usually shortens service life of components, and even leads to serious safety accidents. Therefore, it is of great significance to strengthen the resistance of wear and friction of components at high temperature for improving the reliability in use of components and reducing energy consumption.

Taking full account of the wear reduction mechanism of the common solid lubricant used in high temperature, many researchers found that both the direct addition of solid lubricant and in-situ formation of solid lubrication film with low shear strength could effectively improve tribological performance of the material in elevated temperature [1-3]. For example, Mo and V elements as well as additives which could lead to formation of

* Corresponding authors: Xiaoqin ZHAO, E-mail: zhaoxiaoqin@licp.cas.cn; Yulong AN, E-mail: csuayl@sohu.com 
self-lubricating oxides at high temperature play a vital role in reducing wear rate [4-6]. The addition of $\mathrm{Ag}$, $\mathrm{Au}$, and other compounds with multi-slip system would reduce the friction coefficient due to the softening effect at high temperature [7-10]. Given the two major factors affecting the tribological property of materials at high temperature: the oxidization behavior and the stability of mechanical properties, in-situ formation of oxide film induced by temperature could effectively improve tribological properties. Besides, this method could not only avoid the complexity of the preparation process but also maintain the stable mechanical properties of materials in the high temperature environment. In fact, many alloys would form a glaze layer during friction at high temperature, including Ni-based alloys, Co-based alloys, even high-entropy alloys, and Ti alloys [11-15]. The high hardness of the oxides forming these glaze layers was the essential factor to improve the mechanical properties of materials. For example, $\mathrm{Xu}$ et al. [16] investigated the mechanical properties and high temperature friction properties of high-entropy $\mathrm{FeNiCoCr}$ alloys. It was found that oxides containing $\mathrm{Co}$ and $\mathrm{Cr}$ were formed on the worn surface of the material during friction at high temperature. Among them, the Co-enriched oxides were more favorable to form a dense lubricating glaze layer to reduce the wear rate, and decrease the friction coefficient.

In view of the fact that both oxidation and friction usually occur on the surface of materials, the preparation of coatings can efficiently prevent substrate surface from friction and wear at high temperature. As one of the commonest means for preparing coatings, the high velocity oxygen flame (HVOF) spraying technology has been widely used as preparing coatings to resist wear [17-19]. Its advantages include the low porosity, controllable thickness of preparing coatings, and no damage to the substrate [20]. As for the most familiar HVOF spraying coating, the Ni-based alloy coatings can maintain the great wear resistance and excellent oxidation resistance at a wide temperature range. In order to endow Ni-based alloys with more excellent mechanical strength and wear resistance at high temperature, it is the effective method to introduce many elements with high temperature stability and solution strengthening effect into Ni-based alloy coating. For example, $\mathrm{Cr}$ element easily forms chromium carbide, chromium boride, and other hard phases with C, B, and other elements at high temperature to improve the hardness and wear resistance of the alloy coating [21, 22]. Besides, when the $\mathrm{Cr}_{2} \mathrm{O}_{3}$ oxides were formed and distributed over the coating surface when the temperature rose up, it also could improve hardness and reduce friction coefficient $[23,24]$. NiCrWMoCuCBFe coating belongs to Ni-based alloy coating, which contains $\mathrm{Cr}, \mathrm{W}$, Mo, and other solid solution strengthening elements. As $\mathrm{W}$ and Mo elements with larger atomic radii were dissolved into the coating, serious lattice distortion would happen to the element $\mathrm{Ni}$. The lattice distortion was likely to hinder the diffusion of elements, and improve the chemical stability of the alloy coating at high temperature $[25,26]$. In addition, the high melting point of elements such as $\mathrm{W}$ and Mo might also produce high hardness oxides, carbides, and borides at elevated temperature, which can improve both mechanical properties and wear resistance of the coating [27-29]. At present, it had been found that NiCrWMoCuCBFe coating possesses excellent mechanical properties, corrosion resistance, and cavitation erosion resistance [30-33]. However, there were few studies on its tribological properties at high temperature.

In this study, NiCrWMoCuCBFe coating was prepared by HVOF spraying technology, and its tribological behavior was investigated from 25 to $800{ }^{\circ} \mathrm{C}$. With the aid of high temperature Vickers hardness tester and high temperature X-ray diffraction (XRD) tester, the mechanical properties and chemical composition of $\mathrm{NiCrWMoCuCBFe}$ coating at high temperature were measured in-situ. Combined with mechanical properties and chemical composition of this coating at different temperatures, the tribological mechanism of the coating was discussed. The aim is to clarify the effect of in-situ formation of "glaze" layer on the tribological performance of $\mathrm{NiCrWMoCuCBFe}$ coating at $800{ }^{\circ} \mathrm{C}$, and provide sufficient technical reference and theoretical basis for the application of $\mathrm{NiCrWMoCuCBFe}$ coating about friction at high temperature environment.

\section{Experimental}

\subsection{Preparation of NiCrWMoCuCBFe coating}

The spraying powders were commercial $\mathrm{NiCrWMoCuCBFe} \mathrm{powders} \mathrm{which} \mathrm{was} \mathrm{water} \mathrm{atomized,}$ 
and its nominal chemical composition is shown in Table 1 . The sprayed substrates were $316 \mathrm{~L}$ stainless steels (022Cr17Ni12Mo2) with the size of $\Phi 25 \mathrm{~mm} \times$ $7.8 \mathrm{~mm}$. In order to improve the bonding strength between coating and substrate, the sprayed surfaces of the substrates were sandblasted by sandblasting equipment (GS-943; Beijing Changkong Sand Blasting Equipment Co., Ltd., Beijing, China).

Then these sandblasted samples were placed in acetone solution for $20 \mathrm{~min}$ ultrasonic cleaning to remove oil stains and impurities. The samples were fixed to ensure that the HVOF flame flow was perpendicular to the sample surfaces during spraying. At the same time, the HVOF spray gun (Diamond Jet 2700, Sulzer Metco, USA) was installed on an automatic mechanical arm (IRB 2400/16, ABB, Switzerland) for spraying in order to ensure the consistency of coating. The specific spraying parameters are shown in Table 2.

Table 1 Nominal element composition of NiCrWMoCuCBFe powder.

\begin{tabular}{ccccccccc}
\hline Elements & $\mathrm{Ni}$ & $\mathrm{Cr}$ & $\mathrm{W}$ & $\mathrm{Mo}$ & $\mathrm{Cu}$ & $\mathrm{C}$ & $\mathrm{B}$ & $\mathrm{Fe}$ \\
\hline $\mathrm{wt} \%$ & 54 & 20.5 & 10 & 9 & 4 & 0.75 & 0.75 & 1 \\
\hline
\end{tabular}

Table 2 Spraying parameters of NiCrWMoCuCBFe coating.

\begin{tabular}{cc}
\hline Item & Value \\
\hline Oxygen flow $\left(\mathrm{m}^{3} / \mathrm{h}\right)$ & 19.8 \\
Natural gas flow $\left(\mathrm{m}^{3} / \mathrm{h}\right)$ & 13.1 \\
Air flow rate $\left(\mathrm{m}^{3} / \mathrm{h}\right)$ & 18.7 \\
Nitrogen carrier gas flow $\left(\mathrm{m}^{3} / \mathrm{h}\right)$ & 0.9 \\
Powder feed rate $(\mathrm{g} / \mathrm{min})$ & 25.0 \\
Gun speed $(\mathrm{mm} / \mathrm{s})$ & 800.0 \\
Spraying distance $(\mathrm{cm})$ & 27.0 \\
\hline
\end{tabular}

\subsection{Tribological experiments}

Before tribological testing, 320, 800, 1,500, and 2,000 mesh $\mathrm{SiC}$ sandpapers and diamond paste with a particle size of about $0.5 \mu \mathrm{m}$ were used to grind and polish the prepared samples surfaces to make their roughness level at $\mathrm{Ra} \approx 0.1 \pm 0.02 \mu \mathrm{m}$. The experiments were carried out using a pin-on-disk tribometer at high temperature (CSM, Switzerland), and the friction coefficient curves of the coating at $25,200,400,600$, and $800{ }^{\circ} \mathrm{C}$ were real-time recorded. In the tribological experiment, the $\mathrm{Si}_{3} \mathrm{~N}_{4}$ balls with the diameter of $6 \mathrm{~mm}$ were used. The experimental load was $5 \mathrm{~N}$, the rotation radius was
$5 \mathrm{~mm}$, the friction distance was $300 \mathrm{~m}$, and the linear velocity was $10 \mathrm{~cm} / \mathrm{s}$. Each experiment was repeated three times.

\subsection{Characterization of mechanical properties}

The Vickers microhardness of $\mathrm{NiCrWMoCuCBFe}$ coating at $25,200,400,600$, and $800{ }^{\circ} \mathrm{C}$ was measured in-situ by high temperature Vickers hardness test system (HTR\&V-1200, Archimedes, USA) at argon atmosphere. The heating rate was set at $20^{\circ} \mathrm{C}$ per minute and the holding time was $20 \mathrm{~min} .10$ points were tested at each target temperature, and the average microhardness value was obtained. During measuring, the load was fixed at $300 \mathrm{~g}$, and the dwelling time was $10 \mathrm{~s}$. Then, a microhardness tester (MH-5-VM, Shanghai Embedway Information Technologies Co., Ltd., China) was used to measure the Vickers microhardness of the coating on their wear tracks and non-worn surfaces at each testing temperature. There were ten points tested at each sample, and the average microhardness value was calculated.

\subsection{Microstructure characterization}

An optical microscope (Olympus, Reco, Tokyo, Japan) was used to obtain images of the different areas on the as-polished NiCrWMoCuCBFe coating surface. The porosity of each image was calculated by Image J software. Finally, the average porosity of ten images was calculated as the porosity of the coating. Besides, the JSM-5600LV scanning electron microscopy (SEM; JEOL, Japan) was used to observe the surface morphology of $\mathrm{NiCrWMoCuCBFe}$ powder and coating before and after friction experiment. And a three-dimensional (3D) surface profilometer (MicroXAM-3D, ADE Corporation, USA) was used to obtain the 3D morphology and the roughness on wear scars of these samples after tribological experiments at different environment temperature. In addition, the wear volume of the samples was obtained by Eq. (1), and the wear rate was calculated by Eq. (2):

$$
\begin{gathered}
V=2 \pi r V_{0} \\
\omega=\frac{V}{S F}
\end{gathered}
$$

where $V$ is the wear volume $\left(\mathrm{mm}^{3}\right), V_{0}$ is the wear 
volume of actual length with $1 \mathrm{~mm}$ which can be obtained directly by the 3D surface profilometer, $r$ is the rotation radius during friction, $\omega$ is the wear rate of the coating $\left(\mathrm{mm}^{3} \cdot \mathrm{N}^{-1} \cdot \mathrm{m}^{-1}\right), S$ is the wear distance $(\mathrm{m})$, and $F$ is the load on the sample during friction $(\mathrm{N})$.

In addition, high temperature $\mathrm{X}$-ray diffractometer (Rigaku, Ultima, Japan) was used to analyze the chemical composition of the coating surface under vacuum environment at $25,200,400,600$, and $800^{\circ} \mathrm{C}$. The sample dimensions used were $7 \mathrm{~mm} \times 7 \mathrm{~mm} \times 3 \mathrm{~mm}$, and the excitation source of X-ray diffractometer was $\mathrm{Cu} \mathrm{K} \alpha$ ray $(\lambda=1.54056 \AA, 40 \mathrm{kV}, 40 \mathrm{~mA})$. The scanning range was $10^{\circ}-80^{\circ}$, and the scanning step size was $0.02^{\circ}$. After the tribological experiment, the element distributions on the surfaces of the worn and unworn coatings were measured by energy dispersive $\mathrm{X}$-ray diffraction spectrometer (D8Discover25, Bruker, Germany). Besides, a microscopic confocal Raman spectrometer (JobinYvon HR-800, Horiba, France) was used to analyze the chemical composition of the coating after friction in $25,200,400,600$, and $800^{\circ} \mathrm{C}$. The Argon-ion $(\lambda=532 \mathrm{~nm})$ was used as the excitation light source for the micro confocal Raman spectrometer. In addition, the focused ion beams (FIB) equipment (Helios G4, Waltham, USA) was used to prepare the polished coating and the cross-section worn surface after friction at $800{ }^{\circ} \mathrm{C}$. And transmission electron microscopy (TEM; TECNAI
G2 S-TWIN, F20, USA) was used to observe their microstructure.

\section{Results}

\subsection{Microstructure of powder and as-sprayed coating}

Figure 1 shows the SEM morphology of $\mathrm{NiCrWMoCuCBFe}$ powder, sprayed coating surface, and cross-section surface. It can be seen that the spraying powder was quasi-spherical with smooth surface, and its particle size was about $10-50 \mu \mathrm{m}$. Some particles with smaller size were embedded in the powder particles with larger size (Fig. 1(a)), which may be attributed to the characteristics of water atomization. Besides, there were not only agglomerated particles on the as-sprayed coating surface but also some plastically deformed particles (Fig. 1(b)). It can be seen from the fractured morphology that the prepared coating had an obvious lamellar structure, and there were some powders embedded inside the coating (Fig. 1(c)).

According to the cross-section morphology of $\mathrm{NiCrWMoCuCBFe}$ coating, the thickness of the prepared coating was uniform, about $450 \mu \mathrm{m}$ (Fig. 2(a)). Figure 2(b) shows the TEM morphology of cross-section surface of $\mathrm{NiCrWMoCuCBFe}$ coating (the red line in
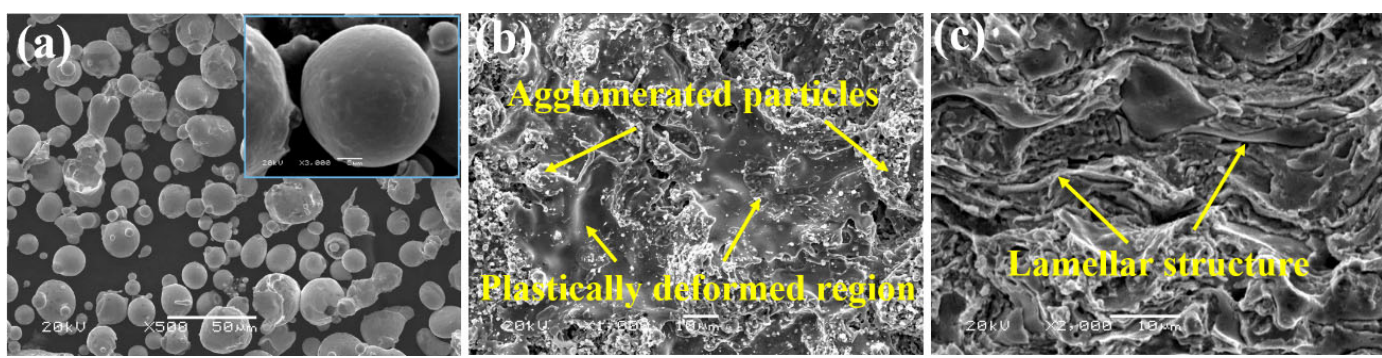

Fig. 1 SEM images of (a) NiCrWMoCuCBFe powder, (b) surface and (c) fracture surface of NiCrWMoCuCBFe coating.
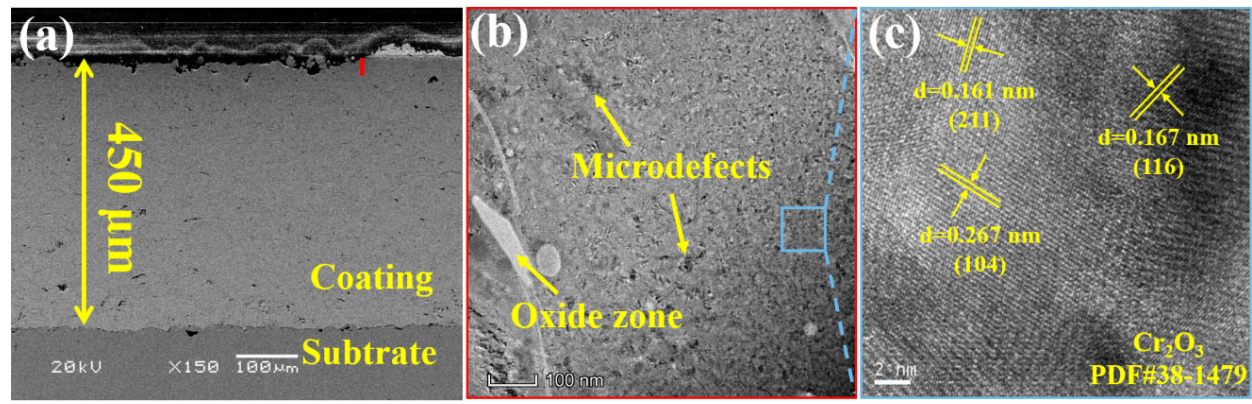

Fig. 2 (a) SEM, (b) bright-field TEM, and (c) HRTEM images of cross-section surface of NiCrWMoCuCBFe coating. 
Fig. 2(a)). It can be seen that there are a few micro defects and slight oxidation inside the coating. And the porosity of the coating was still maintained a low level of $3.24 \% \pm 0.53 \%$. A few $\mathrm{Cr}_{2} \mathrm{O}_{3}$ particles can be observed from the high-resolution TEM (HRTEM) morphology of NiCrWMoCuCBFe coating (Fig. 2(c)), which is attributed to the inevitable oxidation of powder particles as they were molten during spraying.

However, it can be found that the XRD peaks of $\mathrm{NiCrWMoCuCBFe}$ coating and powder were basically consistent (Fig. 3), which mainly belonged to Ni-based solid solutions and $\mathrm{Cr}_{23} \mathrm{C}_{6}$. Meanwhile, there were no significant oxide diffraction peaks. In addition, full width of half maximum of the diffraction peak of $\mathrm{NiCrWMoCuCBFe}$ coating was larger than that of the powder. That is, there was incomplete grains formed or the effect of solid solution strengthening generated during the coating preparation, resulting in lattice distortion inside the coating. The strengthening intensity of diffraction peaks of $\mathrm{Cr}_{23} \mathrm{C}_{6}$ also means that solid solution effect was generated in the process of coating preparation, leading to the increase of its content.

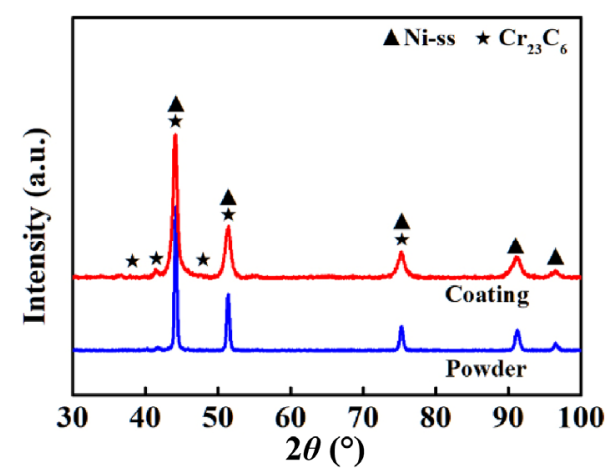

Fig. 3 XRD pattern of NiCrWMoCuCBFe powder and coating.

\subsection{The friction behavior of NiCrWMoCuCBFe coating at elevated temperature}

It can be seen from real-time friction coefficients that the friction coefficients of $\mathrm{NiCrWMoCuCBFe}$ coating at different temperatures was all fluctuated greatly at the beginning of friction (Fig. 4(a)). Especially at $200{ }^{\circ} \mathrm{C}$, the friction coefficient of the coating increased continuously from the lowest of 0.52 (when the friction distance reached about $30 \mathrm{~m}$ ) to the stable 0.84 (after friction of approximately $200 \mathrm{~m}$ ). Compared to that at $200{ }^{\circ} \mathrm{C}$, the shorter running-in period was exhibited at $25,400,600$, and $800^{\circ} \mathrm{C}$. And their friction coefficients were almost stable after friction around $50 \mathrm{~m}$. The average friction coefficient at different temperatures can be calculated by friction coefficients at stable stage. Meanwhile, Fig. 4(b) displays that the average friction coefficient showed a decreasing trend with the increase of temperature. At $25^{\circ} \mathrm{C}$, the average friction coefficient was about 0.86 . When the temperature rose to $800{ }^{\circ} \mathrm{C}$, it decreased down to 0.37. Besides, in Fig. 4(b), the wear rate of the coating firstly increased, and then decreased when the environment temperature increased. The highest wear rate of the coating was about $2.103 \times$ $10^{-4} \mathrm{~mm}^{3} \cdot \mathrm{N}^{-1} \cdot \mathrm{m}^{-1}$ at $400{ }^{\circ} \mathrm{C}$. And the lowest wear rate was only about $5.067 \times 10^{-6} \mathrm{~mm}^{3} \cdot \mathrm{N}^{-1} \cdot \mathrm{m}^{-1}$ at $800^{\circ} \mathrm{C}$, which was lower 2 orders of magnitude than that at $400{ }^{\circ} \mathrm{C}$. In other words, $\mathrm{NiCrWMoCuCBFe}$ coating possessed the most stable and the smallest friction coefficient, as well as the lowest wear rate at $800^{\circ} \mathrm{C}$.

The width of wear scars on $\mathrm{NiCrWMoCuCBFe}$ coating increased at first and then decreased, as can be seen in Fig. 5 . The width of wear scars at $400{ }^{\circ} \mathrm{C}$ $\left(930 \mu \mathrm{m}\right.$, in Fig. 5( $\left.\left.c_{1}\right)\right)$ was more than twice that at $800{ }^{\circ} \mathrm{C}\left(400 \mu \mathrm{m}\right.$, in Fig. $\left.5\left(\mathrm{e}_{1}\right)\right)$. It can be seen from the $3 \mathrm{D}$ morphology that the depth of wear scars was the largest at $400{ }^{\circ} \mathrm{C}$ (Fig. $5\left(\mathrm{c}_{2}\right)$ ), followed by that at $600{ }^{\circ} \mathrm{C}$ (Fig. $5\left(\mathrm{~d}_{2}\right)$ ). After friction at 25 and $400{ }^{\circ} \mathrm{C}$, many furrows appeared on the worn surface (Figs. $5\left(a_{1}\right)$ and $5\left(c_{1}\right)$ ). These furrows were parallel to the friction direction. A small amount of wear debris was distributed at the exit of the sliding counterpart (Figs. $5\left(a_{3}\right)$ and $5\left(c_{3}\right)$ ), which belonged to the main feature of abrasive wear. As for $200^{\circ} \mathrm{C}$, the roughness was the largest and there were some spalling trails presented on the worn surface (Fig. 5(b $\left.b_{1}\right)$ ). Likewise, a large amount of wear debris was also found at the interface (Fig. $5\left(b_{3}\right)$ ). However, when the temperature increased up to $600{ }^{\circ} \mathrm{C}$, there were much wear debris except for furrows existed in the wear scars (Fig. $\left.5\left(\mathrm{~d}_{1}\right)\right)$. Besides, the worn surface was relatively smooth and the amounts of debris were reduced at $800{ }^{\circ} \mathrm{C}$ (Fig. 5( $\left.\mathrm{e}_{1}\right)$ ). Similarly, a transfer film developed at the interface after friction at 600 and $800{ }^{\circ} \mathrm{C}\left(\right.$ Figs. $5\left(\mathrm{~d}_{3}\right)$ and $5\left(\mathrm{e}_{3}\right)$ ). Based on the SEM morphology of wear scars of $\mathrm{NiCrWMoCuCBFe}$ coating and $\mathrm{Si}_{3} \mathrm{~N}_{4}$ counterpart at different temperatures, the wear mechanism of NiCrWMoCuCBFe coating can be summarized as shown in Table 3. At room temperature, the wear behavior of the coating was mainly abrasive. When the temperature rose to $200{ }^{\circ} \mathrm{C}$ or even $400{ }^{\circ} \mathrm{C}$, adhesive and 

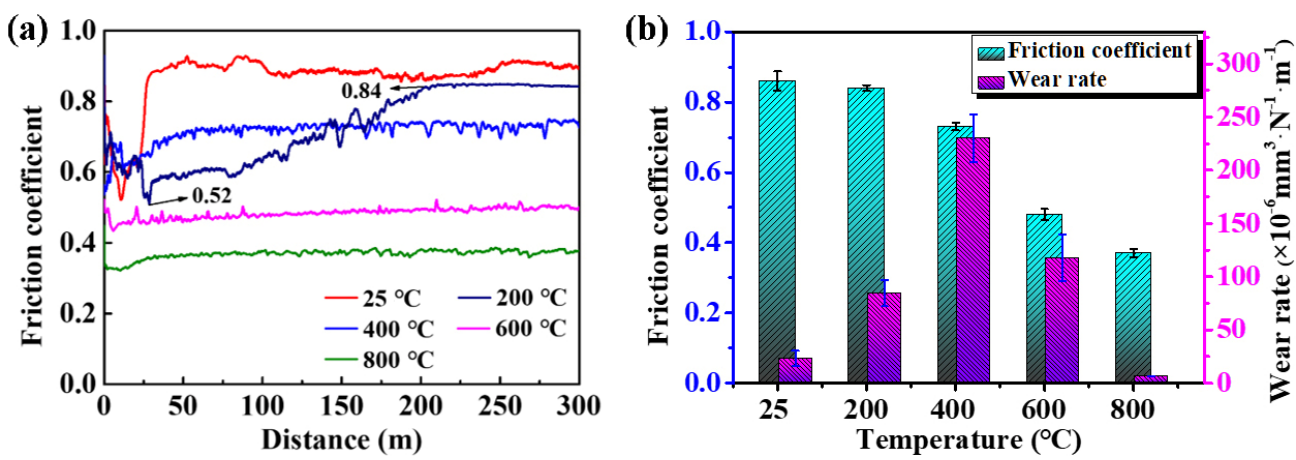

Fig. 4 (a) Real-time friction coefficients, and (b) average friction coefficient and wear rate at elevated temperature of $\mathrm{NiCrWMoCuCBFe}$ coating.

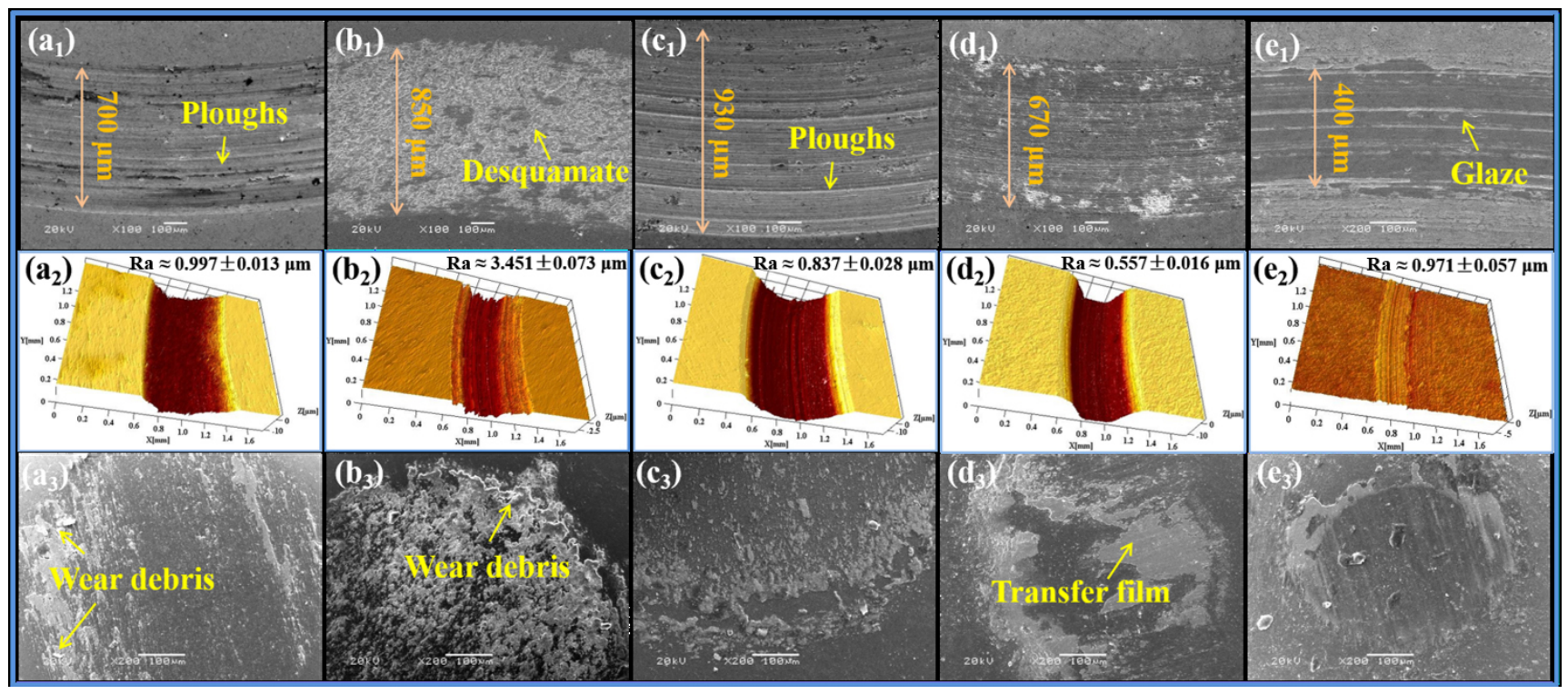

Fig. 5 SEM images of wear scars of $\left(a_{1}\right)$ NiCrWMoCuCBFe coating and $\left(a_{3}\right) \mathrm{Si}_{3} \mathrm{~N}_{4}$ counterpart, $\left(\mathrm{a}_{2}\right)$ 3D morphology of wear scars on the coating surface at $25{ }^{\circ} \mathrm{C}$; and the corresponding morphologies at $\left(\mathrm{b}_{1}-\mathrm{b}_{3}\right) 200{ }^{\circ} \mathrm{C},\left(\mathrm{c}_{1}-\mathrm{c}_{3}\right) 400{ }^{\circ} \mathrm{C},\left(\mathrm{d}_{1}-\mathrm{d}_{3}\right) 600{ }^{\circ} \mathrm{C}$, and $\left(\mathrm{e}_{1}-\mathrm{e}_{3}\right) 800{ }^{\circ} \mathrm{C}$.

Table 3 Wear mechanism of NiCrWMoCuCBFe coating at different temperatures.

\begin{tabular}{cc}
\hline Wear temperature $\left({ }^{\circ} \mathrm{C}\right)$ & Wear mechanism \\
\hline 25 & Abrasive \\
200 & The combined action of abrasive and adhesive \\
400 & The combined action of abrasive and adhesive \\
600 & Compacted oxide film and adhesive \\
800 & Glaze and compacted oxide film \\
\hline
\end{tabular}

abrasive wear acted together. And then the temperature rose to 600 and $800{ }^{\circ} \mathrm{C}$, oxidative wear played a dominant role. From Fig. 5, it can be seen that the agglomerated wear particles appeared in the worn surface of coating and counterpart after friction at $200{ }^{\circ} \mathrm{C}$ (Figs. 5( $\left.\mathrm{b}_{1}\right)$ and $\left.5\left(\mathrm{~b}_{3}\right)\right)$ and $400{ }^{\circ} \mathrm{C}$ (Figs. 5( $\left.\mathrm{c}_{1}\right)$ and $\left.5\left(c_{3}\right)\right)$. Suh et al. $[34,35]$ had also found that many wear particles were likely to be penetrated into the sliding surface under the action of frictional shear force without lubricants, and then these agglomerated particles exited the interface as oxidized thin sheets under the combined effect of load and temperature. Then, this delaminated wear also appeared on the worn surface after friction at $600{ }^{\circ} \mathrm{C}$ (Figs. $5\left(\mathrm{~d}_{1}\right)$ and $\left.5\left(\mathrm{~d}_{3}\right)\right)$. 


\subsection{Oxidation products after friction at elevated temperature}

Figure 6 shows the XRD patterns of $\mathrm{NiCrWMoCuCBFe}$ coating surface after friction at various testing temperatures. These measured XRD diffraction peaks belonged to Ni-ss and $\mathrm{Cr}_{23} \mathrm{C}_{6}$, which is basically consistent with that of the sprayed coating as shown in Fig. 3. When the environment temperature increased to $800{ }^{\circ} \mathrm{C}$, the $\mathrm{XRD}$ peaks on the coating surface were not only the mentioned phases but also appeared the diffraction peaks of $\mathrm{NiO}, \mathrm{Cr}_{2} \mathrm{O}_{3}, \mathrm{Mo}_{2} \mathrm{C}$, and $\mathrm{NiCr}_{2} \mathrm{O}_{4}$. To a certain extent, $\mathrm{NiO}$ and $\mathrm{Cr}_{2} \mathrm{O}_{3}$ can not only enhance the mechanical properties of the alloy, but also play an important role in reducing wear rate and lowering the friction coefficient, because of their high hardness and lubrication effect. The hardness of $\mathrm{Mo}_{2} \mathrm{C}$ was about 10.58-12.65 GPa. Moreover, $\mathrm{Mo}_{2} \mathrm{C}$ possessed a large shear modulus and could play as a lubricant to reduce the friction coefficient of the coating [36, 37].

Raman analysis of NiCrWMoCuCBFe coating after friction at different temperatures was performed on the worn surface, as shown in Fig. 7. The Raman peak of $\mathrm{Si}_{3} \mathrm{~N}_{4}$ can always be detected on the surface of the worn surface because the $\mathrm{Si}_{3} \mathrm{~N}_{4}$ balls were also rubbed in the friction process, resulting in the deposition of wear debris on the worn surface. $\mathrm{Cr}_{2} \mathrm{O}_{3}[38,39]$ firstly appeared on the worn surface of the $\mathrm{NiCrWMoCuCBFe}$ coating surface after friction at $25^{\circ} \mathrm{C}$. When the ambient friction temperature increased to $200{ }^{\circ} \mathrm{C}$, the peak of $\mathrm{NiO}[40,41]$ also appeared in the Raman spectrum. The appearance of the Raman peaks of $\mathrm{NiO}$ and $\mathrm{Cr}_{2} \mathrm{O}_{3}$ can be attributed to two factors. Firstly, the frictional heat generated during sliding was enough to form these oxides even if the environment temperature was still at a low level. Furthermore, there were already a few $\mathrm{Cr}_{2} \mathrm{O}_{3}$ generated during $\mathrm{HVOF}$-spraying process, which can be seen from Fig. 2(c). Similarly, $\mathrm{MoO}_{3}$ [42] appeared on the worn surface when the temperature reached $400{ }^{\circ} \mathrm{C}$. Drawing on the thermodynamics of the oxidation of metal elements, the lower Gibbs free energy of the chemical reaction, the easier to form oxide [43]. According to Eqs. (3) and (4), the Gibbs free energy of several major elements of the coating (as shown in Table 4) in the oxidation process at $800{ }^{\circ} \mathrm{C}$ can be calculated:
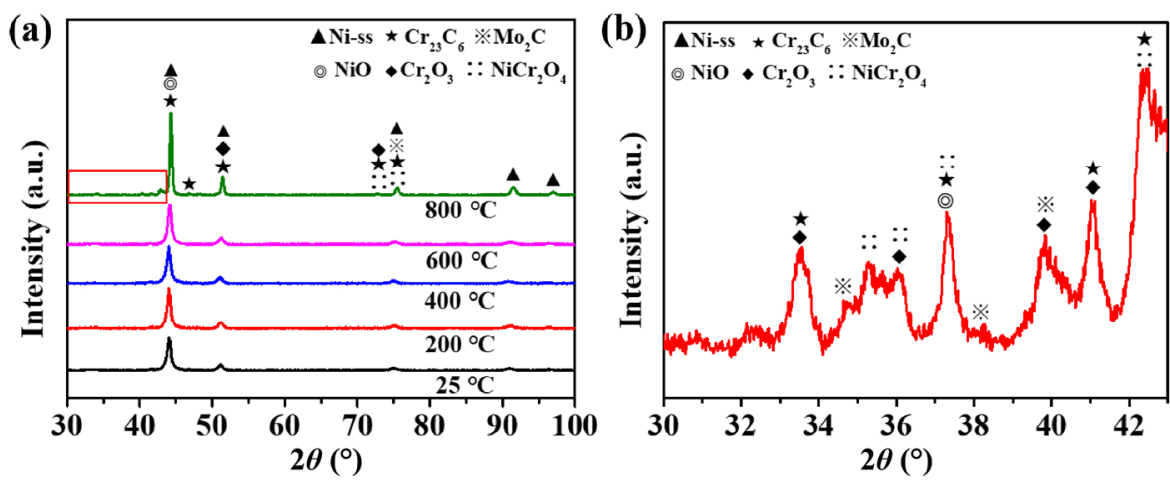

Fig. 6 (a) XRD patterns of NiCrWMoCuCBFe coating after friction at 25, 200, 400, 600, and $800{ }^{\circ} \mathrm{C}$. (b) $30^{\circ}-43^{\circ} \mathrm{XRD}$ patterns of $\mathrm{NiCrWMoCuCBFe}$ coating after friction at $800^{\circ} \mathrm{C}$
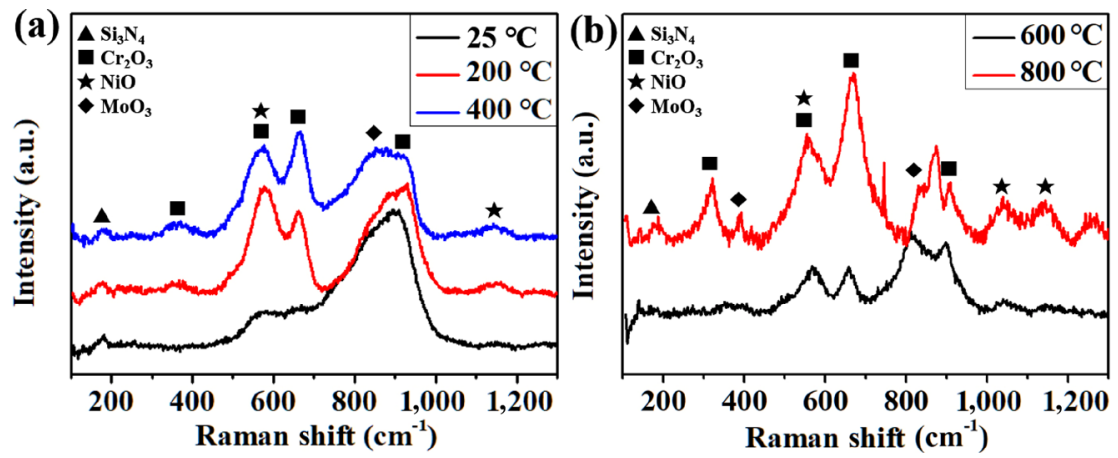

Fig. 7 Raman pattern of NiCrWMoCuCBFe coating after friction (a) at 25,200 , and $400{ }^{\circ} \mathrm{C}$, and (b) at 600 and $800{ }^{\circ} \mathrm{C}$. 
Table 4 Standard Gibbs free energy of several elements of $\mathrm{NiCrWMoCuCBFe}$ coating at $800^{\circ} \mathrm{C}$.

\begin{tabular}{cc}
\hline Chemical reaction & $\Delta_{r} G_{\mathrm{m}}^{\theta}(\mathrm{kJ} / \mathrm{mol})$ \\
\hline $2 \mathrm{Ni}(\mathrm{s})+\mathrm{O}_{2}(\mathrm{~g}) \rightarrow 2 \mathrm{NiO}(\mathrm{s})$ & -334.84 \\
$4 \mathrm{Cr}(\mathrm{s})+3 \mathrm{O}_{2}(\mathrm{~g}) \rightarrow 2 \mathrm{Cr}_{2} \mathrm{O}_{3}(\mathrm{~s})$ & -1830.82 \\
$2 \mathrm{~W}(\mathrm{~s})+3 \mathrm{O}_{2}(\mathrm{~g}) \rightarrow 2 \mathrm{WO}_{3}(\mathrm{~s})$ & -1233.24 \\
$2 \mathrm{Mo}(\mathrm{s})+3 \mathrm{O}_{2}(\mathrm{~g}) \rightarrow 2 \mathrm{MoO}_{3}(\mathrm{~s})$ & -975.08 \\
\hline$\Delta_{r} G_{\mathrm{m}}^{\theta}=\sum_{\mathrm{B}} \vartheta_{\mathrm{B}} \Delta_{\mathrm{f}} G_{\mathrm{m}}^{\theta}(\mathrm{B})$ \\
$\Delta G_{\mathrm{m}}^{\theta}(\mathrm{B})=\Delta H_{\mathrm{m}}^{\theta}(\mathrm{B})-T \Delta S_{\mathrm{m}}^{\theta}(\mathrm{B})$
\end{tabular}

That is, the standard Gibbs free energy difference $\Delta_{r} G_{\mathrm{m}}^{\theta}$ of a chemical reaction was equal to the sum of the standard Gibbs free energy of the product and the reactants. The $\vartheta_{\mathrm{B}}$ means the stoichiometric coefficients of each product and reactant in chemical reaction. The standard Gibbs free energy $\Delta_{r} G_{\mathrm{m}}^{\theta}(\mathrm{B})$ of each reactant and product at $800{ }^{\circ} \mathrm{C}$ is a function of the standard enthalpy of formation $\Delta H_{\mathrm{m}}^{\theta}$ (B) and the standard entropy $\Delta S_{\mathrm{m}}^{\theta}$ (B) of the substance at this temperature. Since the standard Gibbs free energies of $\mathrm{NiO}, \mathrm{Cr}_{2} \mathrm{O}_{3}$, $\mathrm{WO}_{3}$, and $\mathrm{MoO}_{3}$ were all negative, which indicated that these compounds were readily formed at $800{ }^{\circ} \mathrm{C}$.

\section{Discussion}

\subsection{In-situ characterizations of microhardness and oxidation products at high temperatures}

Given the characteristics of oxidation wear [44, 45], the mechanical properties and chemical elements of $\mathrm{NiCrWMoCuCBFe}$ coating at high temperature can directly affect the tribological properties. Thus, it is very necessary to test the Vickers hardness and XRD of NiCrWMoCuCBFe coatings in-situ at different tem- peratures. With the increase of temperature, the in-situ Vickers microhardness value of $\mathrm{NiCrWMoCuCBFe}$ coating measured in Argon showed an overall trend of decline with increasing the environment temperature. That is, the coating softened at high temperature (Fig. 8(a)). Among them, the highest microhardness value was about $629.91 \mathrm{HV}_{300 \mathrm{~g}}$ at $25{ }^{\circ} \mathrm{C}$. The in-situ microhardness value of the coating was $470.89 \mathrm{HV}_{300 \mathrm{~g}}$ at $800{ }^{\circ} \mathrm{C}$, which is significantly lower than that at $25^{\circ} \mathrm{C}$. Besides, the microhardness of the coating at $200{ }^{\circ} \mathrm{C}$ decreased slowly compared with that at $25^{\circ} \mathrm{C}$, indicating that the internal microstructure of the coating still had excellent compressive resistance to the action of external force. However, the microhardness value of the coating dropped sharply as the temperature rose to $600{ }^{\circ} \mathrm{C}$. At this time, the coating underwent obvious plastic deformation subjected to external force.

Opposite trend to in-situ Vickers microhardness at high temperature evolution was observed, the microhardness values of the wear tracks and non-worn surfaces were both enhanced with the increase of temperature (Fig. 8(a)). The microhardness of the non-worn surfaces after friction at $800{ }^{\circ} \mathrm{C}$ increased by $34.46 \%$ compared with that at $25^{\circ} \mathrm{C}$, mainly due to the oxidation generated under the action of high temperature. To be specific, the formation of these high hardness compounds, e.g., $\mathrm{NiO}, \mathrm{Cr}_{2} \mathrm{O}_{3}, \mathrm{Mo}_{2} \mathrm{C}$, and $\mathrm{NiCr}_{2} \mathrm{O}_{4}$, would have great ability to improve the microhardness of the coating surface and reduce wear rate. In addition, the microhardness of the wear tracks improved gradually with the increase of friction temperature. At the same time, it can be seen that the microhardness in the wear tracks was significantly higher than that in the non-worn surface under the

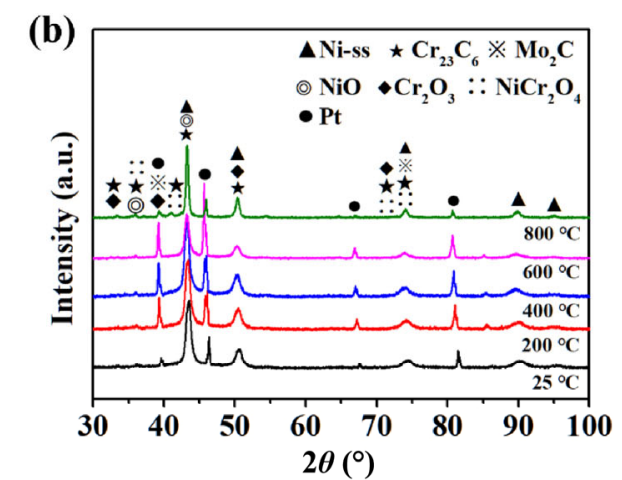

Fig. 8 (a) In-situ microhardness values on the coating surface at $25,200,400,600$, and $800{ }^{\circ} \mathrm{C}$, and micro-hardness values of non-wear scars and worn surface after friction. (b) In-situ XRD of NiCrWMoCuCBFe coating at 25, 200, 400, 600, and $800^{\circ} \mathrm{C}$. 
same condition. The reasons can be ascribed to two aspects. On the one hand, the oxide content of the wear track was likely to increase with the combined action of frictional heat and ambient heat, thus improving the hardness value of the wear track. On the other hand, the effects of work hardening which is caused by the action of repeated sliding would result in the increase of microhardness values of the worn surfaces compared to the unworn ones under corresponding conditions.

The in-situ formation of oxidation products measured by high temperature XRD was still dominated by $\mathrm{NiO}, \mathrm{Cr}_{2} \mathrm{O}_{3}, \mathrm{MoO}_{3}$, and $\mathrm{NiCr}_{2} \mathrm{O}_{4}$ (Fig. 8(b)), which was basically same as the products generated on the worn surface after friction in the Section 3.3 (Figs. 6 and 7). It also reflected that the oxides generated at high temperature environment would not disappear with the decrease of temperature. Worth mentioning, although the slight oxidation $\left(\mathrm{Cr}_{2} \mathrm{O}_{3}\right.$ can be seen in Fig. 2(c)) appeared on the coating surface during HVOF spraying, most of oxides generated when the environment temperature went up. Besides, the peaks of Pt appeared on the XRD pattern. The element Pt came from the sample carrier, which cannot affect the tribology performance of this coating.

\subsection{The generation process of "glaze" layer in high temperature}

Despite a large amount of wear debris, there were grooves, pitting, and spalling appeared on the surface of the worn surface of $\mathrm{NiCrWMoCuCBFe}$ coating after friction at medium and low temperatures (Figs. $9\left(a_{1}\right)$ and $\left.9\left(a_{2}\right)\right)$. The $\mathrm{Si}_{3} \mathrm{~N}_{4}$ counterpart would be pressed into the coating under the action of load, generating severe plastic deformation on the coating surface (Fig. 9(a $\left.a_{1}\right)$ ). Under further action of the friction force, the brittle damage occurred on the coating surface, resulting in a large amount of hard abrasive debris and many furrows and cracks appeared on the worn surface (Fig. 9( $\left.a_{2}\right)$ ). The generated abrasive debris interlocked with each other during sliding, resulting in a high friction coefficient at $25{ }^{\circ} \mathrm{C}$. When the temperature rose to $200{ }^{\circ} \mathrm{C}$, more wear debris were generated due to the declined hardness of the coating by the effect of high temperature (Figs. $9\left(b_{1}\right)$ and $9\left(b_{2}\right)$ ). When the amount of debris gradually increased, they would hinder each other and then make the friction coefficient increased as well. At this time, wear debris was also crushed into a sheet accumulation in the worn surface, which is termed as wear by delamination When the temperature went up to $400{ }^{\circ} \mathrm{C}$, there were a competition between the declined hardness of the material and the formation of friction products. The declined hardness of the coating would lead to more wear debris generation. However, there were many oxides with high hardness formed due to high temperature in the wear tracks as abrasive particles. As a result, the wear rate increased obviously (Figs. $9\left(c_{1}\right)$ and $9\left(c_{2}\right)$ ).

As the temperature rose to 600 and $800{ }^{\circ} \mathrm{C}$, lubrication glazes began to appear on the worn surface (Figs. 10 $\left(\mathrm{a}_{1}\right)$ and $\left.10\left(b_{1}\right)\right)$. The onset of glaze layer formation had an important role in reducing the friction coefficient and wear rate. Besides, it had been found on the worn
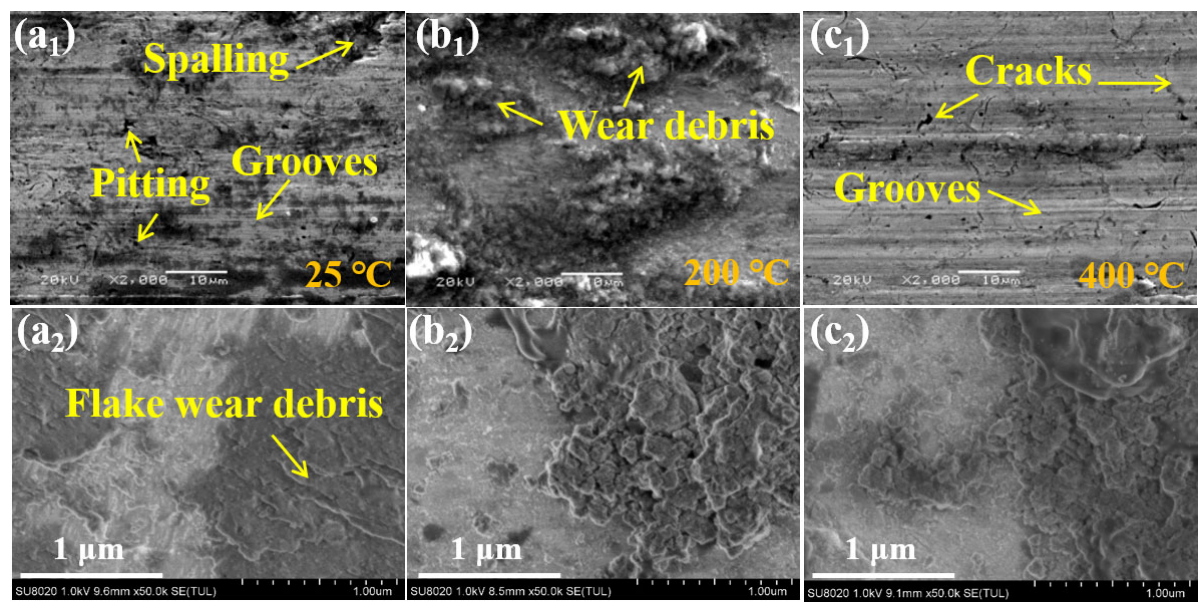

Fig. 9 Local magnification SEM images of worn surface of NiCrWMoCuCBFe coating at $\left(\mathrm{a}_{1}\right) 25^{\circ} \mathrm{C}$, $\left(\mathrm{b}_{1}\right) 200{ }^{\circ} \mathrm{C}$, and $\left(\mathrm{c}_{1}\right) 400{ }^{\circ} \mathrm{C}$. HRSEM images of worn surface at $\left(\mathrm{a}_{2}\right) 25^{\circ} \mathrm{C},\left(\mathrm{b}_{2}\right) 200^{\circ} \mathrm{C}$, and $\left(\mathrm{c}_{2}\right) 400^{\circ} \mathrm{C}$. 

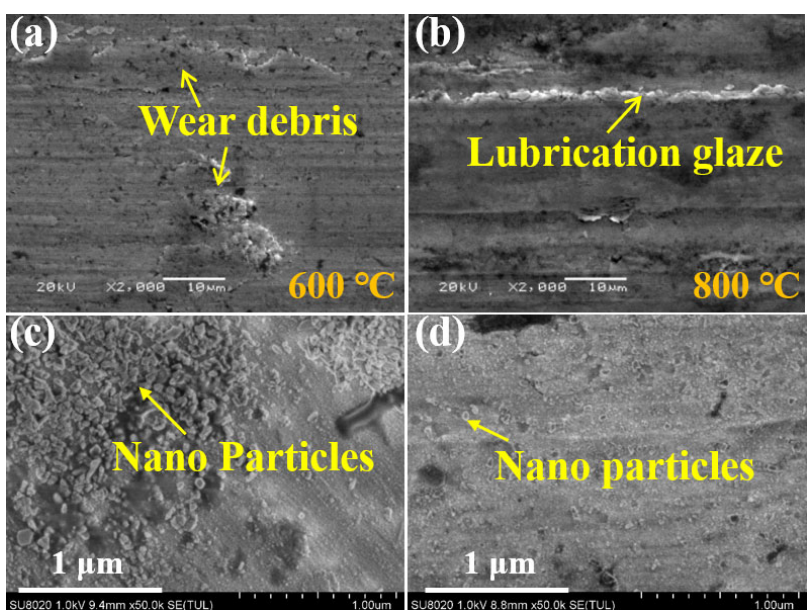

Fig. 10 Magnified SEM images of NiCrWMoCuCBFe coating at (a) $600{ }^{\circ} \mathrm{C}$ and (b) $800^{\circ} \mathrm{C}$. HRSEM images of NiCrWMoCuCBFe coating at (c) $600{ }^{\circ} \mathrm{C}$ and (d) $800{ }^{\circ} \mathrm{C}$.

surface of many Ni-based alloys after friction at high temperature [46-48]. The HRSEM morphology analysis was carried out on the lubrication glaze. A lot of nanoparticles distribute on the glaze layer of coating after friction at 600 and $800{ }^{\circ} \mathrm{C}$ (Figs. $10\left(\mathrm{a}_{2}\right)$ and $\left.10\left(\mathrm{~b}_{2}\right)\right)$. These nanoscale oxides composed of $\mathrm{NiO}, \mathrm{Cr}_{2} \mathrm{O}_{3}, \mathrm{MoO}_{3}, \mathrm{Mo}_{2} \mathrm{C}$, and $\mathrm{NiCr}_{2} \mathrm{O}_{4}$ have great lubrication effect in lowering friction coefficient at the interface. Therefore, the formation of lubrication glazes at high temperature was mainly due to two reasons. On the one hand, the declined hardness of NiCrWMoCuCBFe coating with the increasing of temperature led to the enhancement of the plastic deformation ability. On the other hand, the high temperature environment resulted in the oxidation of the coating surface, thus a large number of hard oxides formed. Therefore, these oxide films on the coating surface were further sintered at high temperatures to form glaze layer with lubricant property when the coating was subjected to friction forces. To sum up, the formation process of the lubricating glaze can be summarized by the following six processes. At first, the inevitable oxidation generated on this coating surface due to the heating process before friction. Subsequently, plastic deformation occurred due to the combined effect of temperature and load between the $\mathrm{Si}_{3} \mathrm{~N}_{4}$ balls and coating surface when friction begun. Therewith, the mutual wear led to the generation of the wear debris on the wear scars. The oxidation of the wear debris caused by high temperature. These oxides mixed and bonded with each other. And finally, the oxides were agglomerated, compacted, and sintered to form a tribo-film due to the combined action of friction shear force and high temperature. This formation of lubricant glaze was consistent with many $\mathrm{Ni}$-based alloy coatings at high temperatures $[49,50]$.

\subsection{The microstructure of "glaze" layer and its influence on wear}

TEM analysis was performed on the lubrication glaze of $\mathrm{NiCrWMoCuCBFe}$ coating after friction at $800{ }^{\circ} \mathrm{C}$. It can be seen that the cross-section morphology of wear scars at $800{ }^{\circ} \mathrm{C}$ was mainly divided into two parts

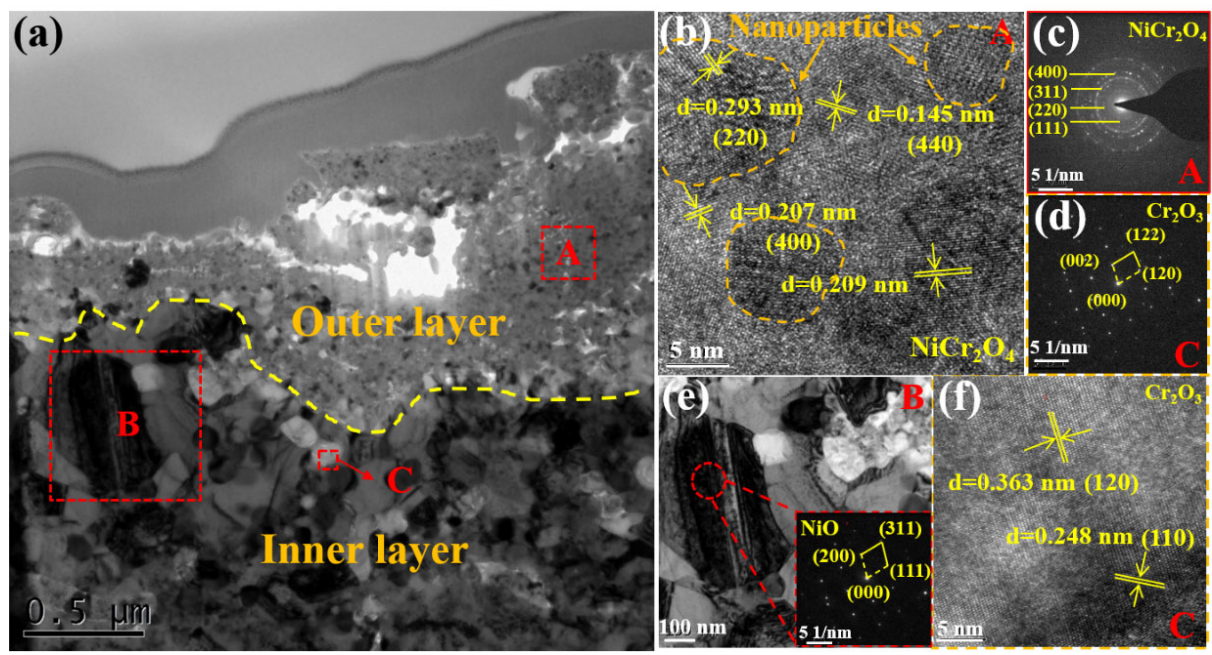

Fig. 11 (a) TEM image of the cross-section surface of wear scar after friction at $800{ }^{\circ} \mathrm{C}$. HRTEM images of (b) " $\mathrm{A}$ " and (f) "C" regions in (a). SAED images of (c) "A" and (d) "C" regions in (a). (e) Local magnified image and corresponding SAED image of "B" region in (a). 
(Fig. 11(a)). The outer layer of coating was the closest to the worn surface, which showed significant cracks and spalling. In addition, there were many nano particles distributed on this part of the wear track (Fig. 11(a)). The size of these grains was very small, almost less than $10 \mathrm{~nm}$. The small grain size was also caused by the combined effect of high temperature and friction force, resulting in grain refinement. From HRTEM and selected area electron diffraction (SAED) analysis of " $\mathrm{A}$ " region, it showed that the region was dominated by spinel $\mathrm{NiCr}_{2} \mathrm{O}_{4}$ (Figs. 11(b) and 11(c)). Under the action of friction force and high temperature, the chemical bond of $\mathrm{NiO}$ and $\mathrm{Cr}_{2} \mathrm{O}_{3}$ broke and these two compounds recombined with each other to form the spinel $\mathrm{NiCr}_{2} \mathrm{O}_{4}$, whose chemical reaction equation was shown in Eq. (5):

$$
\mathrm{NiO}+\mathrm{Cr}_{2} \mathrm{O}_{3} \rightarrow \mathrm{NiCr}_{2} \mathrm{O}_{4}
$$

Among them, $\mathrm{O}^{2-}$ was cubic close packing structure, $\mathrm{Ni}^{2+}$ was filled in the tetrahedral interstice, and $\mathrm{Cr}^{3+}$ was located in octahedral interstice $[47,51,52]$. The formation process and chemical structure of $\mathrm{NiCr}_{2} \mathrm{O}_{4}$ were shown in Fig. 12.

In addition, many grains with different sizes could be seen in the inner layer of the wear track. After the analysis of regions " $\mathrm{B}$ " and " $\mathrm{C}$ ", it was found that these nanocrystals were mainly $\mathrm{NiO}$ and $\mathrm{Cr}_{2} \mathrm{O}_{3}$ (Figs. 11(d)11(f)). There existed substructure inside $\mathrm{NiO}$ grains and the sub-grain boundaries were perpendicular to the worn surface (Fig. 11(e)). Generally, since a large number of tangled dislocations were concentrated on grain boundaries, the generation of sub grain boundaries would prevent the dislocation going through, thus the mechanical properties of the coating could be strengthened.

In summary, the friction and wear mechanism of NiCrWMoCuCBFe coating at $800{ }^{\circ} \mathrm{C}$ is shown in Fig. 13 . Because the outer layer of the coating was in contact with the $\mathrm{Si}_{3} \mathrm{~N}_{4}$ counterparts, plastic deformation took place firstly under the coupling action of high temperature and friction force. The lattice distortion of $\mathrm{NiCrWMoCuCBFe}$ coating was caused by repeated

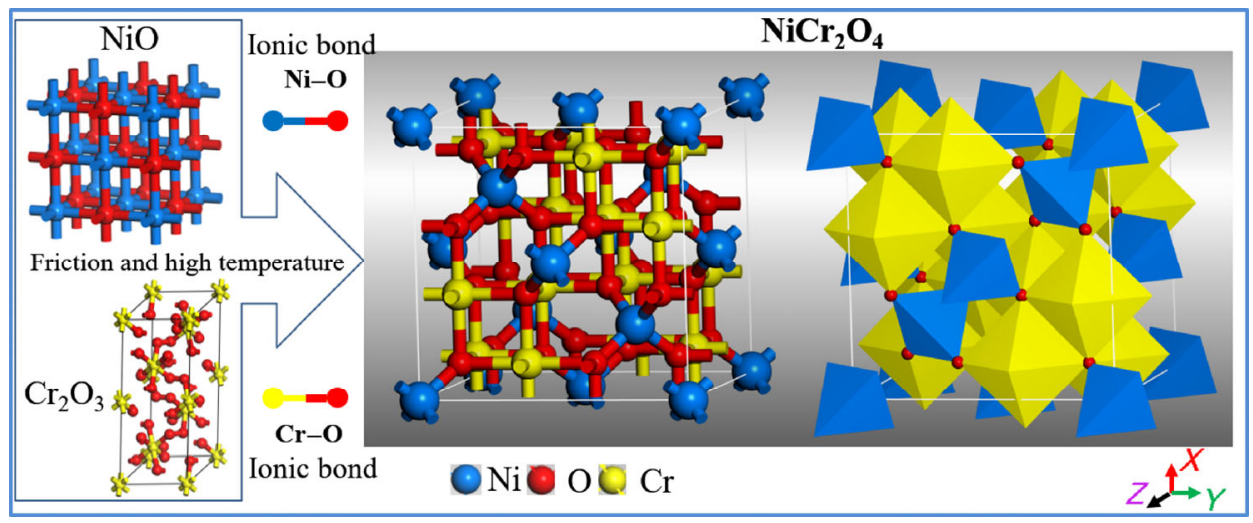

Fig. 12 Chemical structure of $\mathrm{NiO}, \mathrm{Cr}_{2} \mathrm{O}_{3}$, and $\mathrm{NiCr}_{2} \mathrm{O}_{4}$ as well as the formation process of $\mathrm{NiCr}_{2} \mathrm{O}_{4}$.

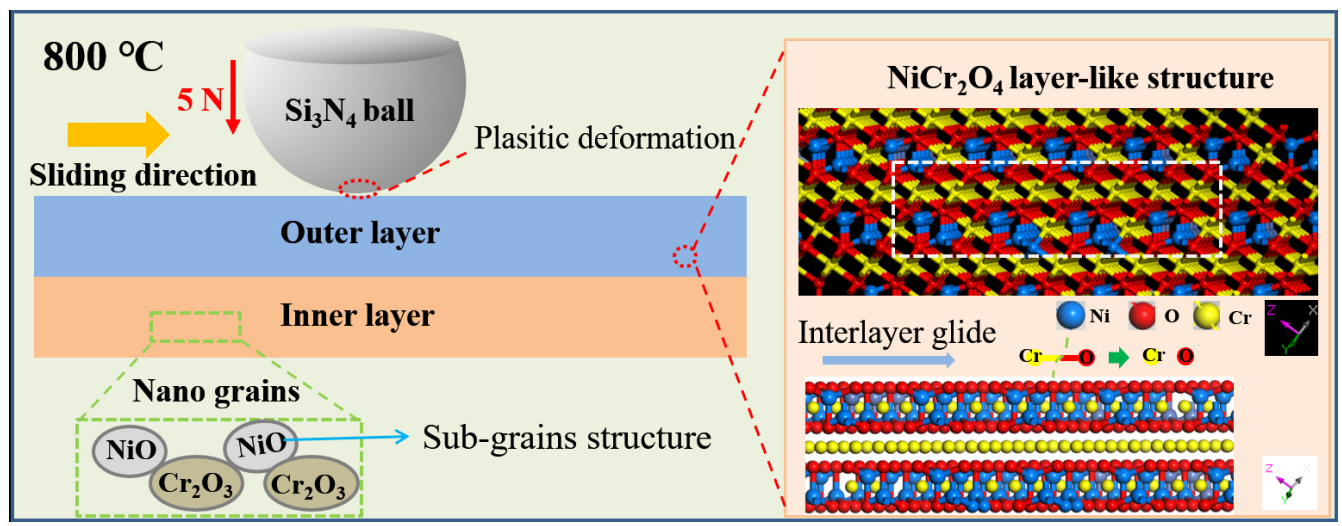

Fig. 13 Friction and wear mechanism of NiCrWMoCuCBFe coating at $800{ }^{\circ} \mathrm{C}$. 
frictional action therewith. In addition, some oxidation products with high hardness such as $\mathrm{NiO}, \mathrm{Cr}_{2} \mathrm{O}_{3}, \mathrm{Mo}_{2} \mathrm{C}$, and $\mathrm{MoO}_{3}$ would be formed in the outer layer because this area was contacted fully with the atmospheric environment. These hard oxide particles were constantly peeled off under the action of friction force, which may form cracks and spalling on the coating surface. Whereafter, the area of the coating exposed to atmospheric environment was increasing, which provided sufficient conditions for further oxidation. At the same time, these oxidation products had lubricant properties that led to reduction of the friction coefficient and wear rate of the coating at $800{ }^{\circ} \mathrm{C}$. Besides, $\mathrm{Ni}, \mathrm{Mo}, \mathrm{Cr}$, and other elements in the coating could diffuse to the surface continually under the action of ambient heat, accelerating the formation of oxide film. As can be seen from Fig. 13, the lamellar $\mathrm{NiCr}_{2} \mathrm{O}_{4}$ oxide film was likely to produce interlaminar shear by friction effect, thus reducing the friction coefficient of the coating [53-56]. Meanwhile, the formation of the oxide film was beneficial to avoid the direct contact between the coating and the $\mathrm{Si}_{3} \mathrm{~N}_{4}$ counterpart to reduce the wear rate of the coating and form a "glaze" layer on the surface. In addition, $\mathrm{NiO}$ and $\mathrm{Cr}_{2} \mathrm{O}_{3}$ nanocrystals comprised the inner layer of the coating. Nano-grains possessed better mechanical properties than coarse grains according to the Hall-Petch equation. Therefore, they would play a supporting role to maintain mechanical strength of the overall coating, though the coating surface had softened at high temperature.

The aforementioned can conclude that the enhancement of friction properties of NiCrWMoCuCBFe coating at high temperature was closely related to the formation of glaze layers on the coating surface. This "glaze" layer was mainly composed of oxides with lubrication and high hardness properties. In low temperature stage, the little generated oxides were not effective in lowering the friction coefficient or improving the mechanical properties of this coating in the friction process. Instead, the softening effect of the coating was dominant, which could explain why the friction coefficient and wear rate were relatively high. However, with the increase of the friction temperature, these increasing oxides began to play a key role in the tribological and mechanical properties of the coating. By reason of the foregoing, it can be seen that $\mathrm{NiCrWMoCuCBFe}$ coating has not only good wear reduction effect and wear resistance but also great high temperature mechanical properties at $800{ }^{\circ} \mathrm{C}$.

\section{Conclusions}

In this study, NiCrWMoCuCBFe coating was prepared by HVOF spraying technology, and its tribological properties at $25,200,400,600$, and $800{ }^{\circ} \mathrm{C}$ were studied. The tribological behaviors of the coating at 600 and $800{ }^{\circ} \mathrm{C}$ were mainly analyzed. Based on in-situ high temperature Vickers hardness tester and high temperature XRD diffractometer, the influence of the mechanical properties and the microstructure on the tribological properties of this coating at high temperature was discussed. The morphology evolution of these wear tracks after high temperature friction was analyzed by HRSEM. Especially, the wear mechanism at $800{ }^{\circ} \mathrm{C}$ was analyzed by TEM in detail. The main conclusions were as follows:

1) Many hard oxides including $\mathrm{NiO}, \mathrm{Cr}_{2} \mathrm{O}_{3}, \mathrm{Mo}_{2} \mathrm{C}$, and $\mathrm{MoO}_{3}$ were generated on the NiCrWMoCuCBFe coating surface after friction at high temperature. The generation of these hard oxides was mainly due to the effect of ambient heat.

2) The friction coefficient and wear rate of $\mathrm{NiCrWMoCuCBFe}$ coating at $800{ }^{\circ} \mathrm{C}$ are the lowest (0.37 and $5.067 \times 10^{-6} \mathrm{~mm}^{3} \cdot \mathrm{N}^{-1} \cdot \mathrm{m}^{-1}$, respectively), which were mainly related to the formation of "glaze" layer on the coating surface at high temperature.

3) The formation of "glaze" layer mainly experienced six processes in high temperature friction: oxidation by high temperature, the plastic deformation, the generation of wear debris, further oxidation of wear debris, the oxides mixed and bonded with each other, and then agglomeration, compaction, sintering, and adherence to one of the counterparts due to the combined action of friction shear force and high temperature.

4) After friction at $800^{\circ} \mathrm{C}$, the "glaze" layer was mainly divided into two parts. The outer layer was mainly composed of hard oxide particles and the $\mathrm{NiCr}_{2} \mathrm{O}_{4}$ oxide film with lamellar structure. Its interlaminar shear caused by friction shear force can effectively reduce the friction coefficient and wear rate of $\mathrm{NiCrWMoCuCBFe}$ coating. The inner layer was mainly nanoparticles with high hardness, which can endow the coating good mechanical properties at high temperature. 


\section{Acknowledgements}

This work was supported by the National Natural Science Foundation of China (No. 51771214) and the Youth Innovation Promotion Association of Chinese Academy of Sciences (No. 2014378).

Open Access This article is licensed under a Creative Commons Attribution 4.0 International License, which permits use, sharing, adaptation, distribution and reproduction in any medium or format, as long as you give appropriate credit to the original author(s) and the source, provide a link to the Creative Commons licence, and indicate if changes were made.

The images or other third party material in this article are included in the article's Creative Commons licence, unless indicated otherwise in a credit line to the material. If material is not included in the article's Creative Commons licence and your intended use is not permitted by statutory regulation or exceeds the permitted use, you will need to obtain permission directly from the copyright holder.

To view a copy of this licence, visit http://creativecommons.org/licenses/by/4.0/.

\section{References}

[1] Rapoport L, Bilik Y, Feldman Y, Homyonfer M, Cohen S R, Tenne R. Hollow nanoparticles of $\mathrm{WS}_{2}$ as potential solidstate lubricants. Nature 387(6635): 791-793 (1997)

[2] Chhowalla M, Amaratunga GAJ. Thin films of fullerene-like $\mathrm{MoS}_{2}$ nanoparticles with ultra-low friction and wear. Nature 407(6801): 164-167 (2000)

[3] Zhu S, Cheng J, Qiao Z, Yang J. High temperature solidlubricating materials: A review. Tribol Int 133: 206-223 (2019)

[4] Muratore C, Voevodin A A, Hu J J, Zabinski J S. Tribology of adaptive nanocomposite yttria-stabilized zirconia coatings containing silver and molybdenum from 25 to $700{ }^{\circ} \mathrm{C}$. Wear 261(7-8): 797-805 (2006)

[5] Hao E, An Y, Chen J, Zhao X, Hou G, Chen J, Gao M, Yan F. In-situ formation of layer-like $\mathrm{Ag}_{2} \mathrm{MoO}_{4}$ induced by hightemperature oxidation and its effect on the self-lubricating properties of NiCoCrAlYTa/Ag/Mo coatings. J Mater Sci Technol 75: 164-173 (2021)

[6] Wang R, Mei H, Li R, Zhang T, Wang Q. Influence of V addition on the microstructure, mechanical, oxidation and tribological properties of AlCrSiN coatings. Surf Coat Technol 407: 126767 (2021)
[7] Ouyang J H, Sasaki S, Murakami T, Umeda K. Tribological properties of spark-plasma-sintered $\mathrm{ZrO}_{2}\left(\mathrm{Y}_{2} \mathrm{O}_{3}\right)-\mathrm{CaF}_{2}-\mathrm{Ag}$ composites at elevated temperatures. Wear 258(9): 14441454 (2005)

[8] Hu J J, Muratore C, Voevodin A A. Silver diffusion and high-temperature lubrication mechanisms of YSZ-Ag-Mo based nanocomposite coatings. Compos Sci Technol 67(3-4): 336-347 (2007)

[9] Tyagi R, Xiong D S, Li J L, Dai J H. Elevated temperature tribological behavior of $\mathrm{Ni}$ based composites containing nano-silver and hBN. Wear 269(11-12): 884-890 (2010)

[10] Zhao D, Li S, Zhao X, Hao E, An Y, Zhou H, Chen J. Preparation and vacuum tribological properties of composite coatings fabricated by effective introduction of soft metal Ag into spray-formed YSZ templates. Appl Surf Sci 518: 146176 (2020)

[11] Pauly V, Kern J, Clark M, Grierson D S, Sridharan K. Wear Performance of incoloy 800HT and inconel 617 in various surface conditions for high-temperature gas-cooled reactor components. Tribol Int 154: 106715 (2021)

[12] Tsigkis V, Bashandeh K, Lan P, Polycarpou A A. Tribological behavior of PS400-related tribopairs for space exploration. Tribol Int 153: 106636 (2021)

[13] Dreano A, Fouvry S, Guillonneau G. Understanding and formalization of the fretting-wear behavior of a cobalt-based alloy at high temperature. Wear 452-453: 203297 (2020)

[14] Xin B, Zhang A, Han J, Meng J. Improving mechanical properties and tribological performance of $\mathrm{Al}_{0.2} \mathrm{Co}_{1.5} \mathrm{CrFeNi}_{1.5} \mathrm{Ti}_{0.5}$ high entropy alloys via doping Si. J Alloys Compd 869: 159122 (2021)

[15] Munagala V N V, Torgerson T B, Scharf T W, Chromik $\mathrm{R}$ R. High temperature friction and wear behavior of cold-sprayed $\mathrm{Ti}_{6} \mathrm{Al}_{4} \mathrm{~V}$ and $\mathrm{Ti}_{6} \mathrm{Al}_{4} \mathrm{~V}-\mathrm{TiC}$ composite coatings. Wear 426-427: 357-369 (2019)

[16] Xu J, Kong X, Chen M, Wang Q, Wang F. High-entropy FeNiCoCr alloys with improved mechanical and tribological properties by tailoring composition and controlling oxidation. J Mater Sci Technol 82: 207-213 (2021)

[17] Lima R S, Marple B R. Thermal spray coatings engineered from nanostructured ceramic agglomerated powders for structural, thermal barrier and biomedical applications: A review. J Therm Spray Technol 16(1): 40-63 (2007)

[18] Jonda E, Łatka L, Pakieła W. Comparison of different cermet coatings sprayed on magnesium alloy by HVOF. Materials 14(7): 1594 (2021)

[19] Ctibor P, Stengl V, Pala Z. Structural and photocatalytic characteristics of $\mathrm{TiO}_{2}$ coatings produced by various thermal spray techniques. J Adv Ceram 2(3): 218-226 (2013)

[20] Fauchais P, Vardelle A, Dussoubs B. Quo vadis thermal spraying? J Therm Spray Technol 10(1): 44-66 (2001) 
[21] Liu Q, Bai Y, Wang H D, Ma G Z, Liu M, Chu C Y, Sun Y W, Fan W, Ding F, Zhao B, et al. Microstructural evolution of carbides and its effect on tribological properties of SAPS or HVOF sprayed $\mathrm{NiCr}-\mathrm{Cr}_{3} \mathrm{C}_{2}$ coatings. J Alloys Compd 803: 730-741 (2019)

[22] Zhang Y, Chong K, Liu Q, Bai Y, Zhang Z, Wu D, Zou Y. High-temperature tribological behavior of thermally-treated supersonic plasma sprayed $\mathrm{Cr}_{3} \mathrm{C}_{2}-\mathrm{NiCr}$ coatings. Int $J$ Refract Met Hard Mater 95: 105456 (2021)

[23] Ouyang J H, Sasaki S, Umeda K. The friction and wear characteristics of plasma-sprayed $\mathrm{ZrO}_{2}-\mathrm{Cr}_{2} \mathrm{O}_{3}-\mathrm{CaF}_{2}$ from room temperature to $800{ }^{\circ} \mathrm{C}$. J Mater Sci 36(3): 547-555 (2001)

[24] Korashy A, Attia H, Thomson V, Oskooei S. Fretting wear behavior of cobalt-Based superalloys at high temperature-A comparative study. Tribol Int 145: 106155 (2020)

[25] Chen Y, Hu R, Kou H, Zhang T, Li J. Precipitation of nanosized DO22 superlattice with high thermal stability in an Ni-Cr-W superalloy. Scr Mater 76: 49-52 (2014)

[26] Pan S, Guan Z, Yao G, Yuan J, Li X. Mo-enhanced chemical stability of TiC nanoparticles in molten Al. J Alloys Compd 856: 158169 (2021)

[27] Jin Y S, Li M Y, Wang Y. The synergistic effects of Mo as an alloy element added to chromium carbide coatings on their lubrication properties at high temperatures. Wear 172(2): 147-154 (1994)

[28] Jia P, Yu L, Shi T, Ju H, Xu J, Gao F. The effect of molybdenum content on microstructure, mechanical, tribological and corrosion behavior of $\mathrm{Zr}-\mathrm{Mo}-\mathrm{N}$ composite films. Mater Today Commun 26: 101720 (2021)

[29] Liu J H, Yan J X, Liu Y D, Li W H, Gu W S, Pei Z L, Gong J, Sun C. Impact of annealing temperature on the microstructure, microhardness, tribological properties and corrosion resistance of Ni-Mo/diamond composites. Appl Surf Sci 541: 148367 (2021)

[30] Bolelli G, Lusvarghi L, Giovanardi R. A comparison between the corrosion resistances of some HVOF-sprayed metal alloy coatings. Surf Coat Technol 202(19): 4793-4809 (2008)

[31] Zhang S H. Improvement on HVOF sprayed Diamalloy coatings by laser irradiation. Appl Phys A 108(1): 201-209 (2012)

[32] Wang Y, Hao E, An Y, Hou G, Zhao X, Zhou H. The interaction mechanism of cavitation erosion and corrosion on HVOF sprayed NiCrWMoCuCBFe coating in artificial seawater. Appl Surf Sci 525: 146499 (2020)

[33] Wang Y, Hao E, An Y, Chen J, Zhou H. Effects of microstructure and mechanical properties on cavitation erosion resistance of NiCrWMoCuCBFe coatings. Appl Surf Sci 547: 149125 (2021)
[34] Suh N P, Mosleh M, Howard P S. Control of friction. Wear 175(1-2): 151-158 (1994)

[35] Suh N P. An overview of the delamination theory of wear. Wear 44(1): 1-16 (1977)

[36] Yang H R, Lee K B, Kwon H. Effects of austenitizing treatments and inclusions on secondary hardening and fracture behavior for high Co-Ni steels containing W. Mater Sci Eng: A 265(1-2): 179-187 (1999)

[37] Liu Y Z, Jiang Y H, Zhou R, Liu X F, Feng J. Elastic and thermodynamic properties of $\mathrm{Mo}_{2} \mathrm{C}$ polymorphs from first principles calculations. Ceram Int 41(4): 5239-5246 (2015)

[38] Zuo J, Xu C, Hou B, Wang C, Xie Y, Qian Y. Raman spectra of NanophaseCr $\mathrm{O}_{2}$. J Raman Spectrosc 27(12): 921-923 (1996)

[39] Gomes A S O, Yaghini N, Martinelli A, Ahlberg E. A micro-Raman spectroscopic study of $\mathrm{Cr}(\mathrm{OH})_{3}$ and $\mathrm{Cr}_{2} \mathrm{O}_{3}$ nanoparticles obtained by the hydrothermal method. J Raman Spectrosc 48(10): 1256-1263 (2017)

[40] Mironova-Ulmane N, Kuzmin A, Steins I, Grabis J, Sildos I, Pärs M. Raman scattering in nanosized nickel oxide NiO. J Phys: Conf Ser 93: 012039 (2007)

[41] Mironova-Ulmane N, Kuzmin A, Sildos I, Pärs M. Polarisation dependent Raman study of single-crystal nickel oxide. Central Eur J Phys 9(4): 1096-1099 (2011)

[42] Silveira J V, Vieira L L, Filho J M, Sampaio A J C, Alves O L, Souza Filho A G. Temperature-dependent Raman spectroscopy study in $\mathrm{MoO}_{3}$ nanoribbons. J Raman Spectrosc 43(10): 1407-1412 (2012)

[43] Fuchs H U. The Dynamics of Heat. In Hotness, Heat, and Energy. Harrison S, Ed. New York: Springer, 1996: 51-152.

[44] Quinn T F J. Review of oxidational wear Part II: Recent developments and future trends in oxidational wear research. Tribol Int 16(6): 305-315 (1983)

[45] Quinn T F J. Review of oxidational wear: Part I: The origins of oxidational wear. Tribol Int 16(5): 257-271 (1983)

[46] Alkelae F, Fouvry S. Identification of parameters influencing the glaze layer formation and stability at high temperature for a Waspaloy/René125 contact under fretting wear conditions. Wear 390-391: 41-48 (2017)

[47] Liang G Y, Zhu C, Wu X Y, Wu Y. The formation model of $\mathrm{Ni}-\mathrm{Cr}$ oxides on NiCoCrAlY-sprayed coating. Appl Surf Sci 257(15): 6468-6473 (2011)

[48] Hong S, Wu Y, Li G, Wang B, Gao W, Ying G. Microstructural characteristics of high-velocity oxygen-fuel (HVOF) sprayed nickel-based alloy coating. J Alloys Compd 581: 398-403 (2013)

[49] Inman I A, Datta S, Du H L, Burnell-Gray J S, Luo Q. Microscopy of glazed layers formed during high temperature 
sliding wear at $750{ }^{\circ} \mathrm{C}$. Wear 254(5-6): 461-467 (2003)

[50] Zhou Y, Sun Z P, Yu Y, Li L, Song J L, Xie F Q, Wu X Q. Tribological behavior of $\mathrm{Ni}-\mathrm{SiC}$ composite coatings produced by circulating-solution electrodeposition technique. Tribol Int 159: 106933 (2021)

[51] Suchomel M R, Shoemaker D P, Ribaud L, Kemei M C, Seshadri R. Spin-induced symmetry breaking in orbitally ordered $\mathrm{NiCr}_{2} \mathrm{O}_{4}$ and $\mathrm{CuCr}_{2} \mathrm{O}_{4}$. Phys Rev B 86(5): 054406 (2012)

[52] Das D, Ghosh S. Density functional theory based comparative study of electronic structures and magnetic properties of spinel $\mathrm{ACr}_{2} \mathrm{O}_{4}(\mathrm{~A}=\mathrm{Mn}, \mathrm{Fe}, \mathrm{Co}, \mathrm{Ni})$ compounds. $J$ Phys $D$ : Appl Phys 48(42): 425001 (2015)

[53] Stott F H, Lin D S, Wood G C. The structure and mechanism

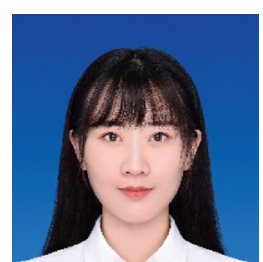

Yijing WANG. She received her bachelor degree of material science and the second bachelor degree of standardization management from China Jiliang University, Hangzhou, China, in 2017. Now, she is a Ph.D.

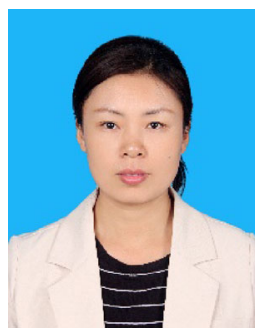

Xiaoqin ZHAO. She serves as a professor and master's advisor in Lanzhou Institute of Chemical Physics, CAS. In 2003, she received her bachelor degree from Chongqing University, Chongqing, China.

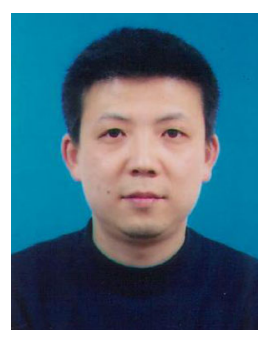

Yulong AN. He is a professor and doctoral supervisor. He received his M.S. degree in 2004 from Central South University, Changsha, China. At the same year, he joined the State Key Laboratory of Solid Lubrication, Lanzhou Institute of of formation of the "glaze" oxide layers produced on nickelbased alloys during wear at high temperatures. Corros Sci 13(6): 449-469 (1973)

[54] Dent A H, Horlock A J, McCartney D G, Harris S J. Microstructural characterisation of a $\mathrm{Ni}-\mathrm{Cr}-\mathrm{B}-\mathrm{C}$ based alloy coating produced by high velocity oxy-fuel thermal spraying. Surf Coat Technol 139(2-3): 244-250 (2001)

[55] H. Edris, D.G. McArtney. Microstructural characterization of high velocity oxy-fuel sprayed coatings of Inconel 625. $J$ Mater Sci 32: 863-872 (1997)

[56] Vasudev H, Thakur L, Singh H, Bansal A. An investigation on oxidation behaviour of high velocity oxy-fuel sprayed Inconel718- $\mathrm{Al}_{2} \mathrm{O}_{3}$ composite coatings. Surf Coat Technol 393: 125770 (2020)

candidate of material science in Lanzhou Institute of Chemical Physics, Chinese Academy of Sciences (CAS). Her current scientific interests are devoted to the surface protection to cavitation erosion, corrosion, and friction of metal materials.

At the same year, she entered Lanzhou Institute of Chemical Physics to pursue for her doctor degree. Then, she received her Ph.D. degree of materials science in 2009. Now, her research areas cover the development and application of thermal spraying functional coatings.

Chemical Physics, CAS. In 2011, he obtained Ph.D. degree of materials science from Lanzhou Institute of Chemical Physics. At present, he focuses on wear resistance, lubrication, thermal protection, corrosion resistance, cavitation erosion resistance, and space anti-cold welding coating research work. 